\title{
Commercialization of Nature: Can Market-Based Mechanisms Deliver Positive Conservation and Development Outcomes?
}

\author{
Sayuni B. Mariki \\ Department of Wildlife Management, Sokoine University of Agriculture, Morogoro, Tanzania \\ Email:zion2000tz@gmail.com,zion@suanet.ac.tz
}

Received 18 May 2016; accepted 12 June 2016; published 15 June 2016

Copyright (C 2016 by author and Scientific Research Publishing Inc.

This work is licensed under the Creative Commons Attribution International License (CC BY). http://creativecommons.org/licenses/by/4.0/

(c) (i) Open Access

\begin{abstract}
Over the past two decades, market-based approaches to natural resources conservation have become a focus in national and international arenas. They are regarded as a means to finance biodiversity conservation. The approaches have emerged, partly because of global environmental challenges as well as a response to growing criticisms levelled against the efficiency of conventional approaches to natural resources conservation. Drawing from numerous case studies, this article aims to demonstrate the extent to which these approaches have managed to deliver win-win outcomes as claimed by its proponents. It synthesizes literature from the current experiences of market-based approaches, and assesses its success with respect to economic, social and environmental impacts. The article contributes to the growing debate about the role of environmental markets for biodiversity conservation and development. The article concludes that despite some weaknesses that market-based conservation approaches exhibit, they are the vital component in efforts to combine conservation and development.
\end{abstract}

\section{Keywords}

Benefits, Conservation, Development, Local People, Markets

\section{Introduction}

Over the past two decades, conservation policy and practice have increasingly turned towards market-based interventions as a means to reconcile environmental conservation and economic development [1]-[4]. The interventions have emerged in response to global environmental issues and challenges including global warming, ozone layer depletion, and failure of environmental legislation to protect environment [5]. This situation re-

How to cite this paper: Mariki, S.B. (2016) Commercialization of Nature: Can Market-Based Mechanisms Deliver Positive Conservation and Development Outcomes? Open Journal of Social Sciences, 4, 61-69. 
quired new strategy of cooperation and negotiation between different actors. Since then, many governments are striving to use market-based mechanisms to resolve environmental problems in diverse ways [5].

Market-based conservation emerged under the notion that if the economic value is apportioned to a resource or a species, users will realise the accrued benefits and thereby use the resources sustainably; thus, it would be the best way of saving it [6] [7]. Moreover, the direct payments received by local communities may provide benefits adequate to compete with alternative land use activities such as agriculture [8]. These benefits accrued will also provide livelihood opportunities for those most affected by conservation initiatives [9]. To date, there is a range of financial mechanisms with the intention of meeting these dual objectives.

Market-based approaches have been implemented for over two decades, but they seem to yield mixed results (e.g. [10]-[12]). This paper draws from different case studies around the world to explore the extent to which these approaches have delivered conservation and development outcomes. The article contributes to growing literature of market-based conservation approaches and whether they are good option for biodiversity conservation and economic development. Lessons learnt from different case studies will provide insights to various actors interested in market-based initiatives as a way of meeting conservation objectives.

This article starts by providing a brief history of conservation with a focus on commercialization. Secondly, it reviews market-based conservation and its two persistent narratives-positive and negative impacts of commercialization. Lastly, findings from various case studies of market-based conservation are analysed. A general conclusion drawn from this review is that, market-based conservation approaches are important in complementing the existing strategies and initiatives aiming at reconciling conservation and development goals.

\section{A Brief History of Conservation with Focus on Commercialization}

Modern conservation dates back to the late $19^{\text {th }}$ Century when the Yellowstone National Park was established in the United States of America. Conservation spread worldwide, largely through colonialism. The main concern was that excessive local resource use was leading to the resource decline and extinction [13]. Europeans believed that Africans hunting for subsistence was barbaric and uncivilized. Sport hunting was perceived in romantic terms as a "civilized sport" for privileged white settlers. Thus, white people were regarded as hunters while black people were called poachers. For instance, Teddy Roosevelt, the $26^{\text {th }}$ President of the United States, in his voyage to East Africa in early 1900s killed over 11,000 animals. However, he was regarded as "The Hunter" and also "Conservationist President" [14].

Colonial period was marked by increased exploitation of natural resources such as wildlife, forests and woodlands. During the First World War, there was intensive forest encroachment as indigenous forests were cleared to establish tea, coffee, commercial crops and timber plantations [15]. Natural resource plundering, land appropriation from local people (colonial primitive accumulation) and unequal exchange were done mainly through violence and force [16]. At this time, several ordinances and policies were enacted and formulated to control natural resource use. For example in Tanzania, the Forest Ordinance of 1957 and the Wildlife Conservation Ordinance of 1959 were enacted in which virtually all customary rights to local communities were withdrawn.

Shortly after World War II, much of the Western world experienced economic boom. However, after the boom, these countries experienced economic stagnation in the 1970s where there was a high unemployment coincided with high inflation [17]. In developing countries, there was a decline in economic growth in the 1970s and 1980s partly as a result of a mix of state-led economy, nationalism, corruption, politics, and populism [17]. The stagflation forced many countries to look for new economic systems. The neoliberalism and other associated economically liberal doctrines emerged as a solution to the problem and swept all over the world [16].

The economic reforms signified a move from a state-led economy and administrative control towards "economic liberalization" and encouragement of "private sector development" [18]. The economic liberalization was a part of the general move intended to give markets a greater role in development. It was also a response to numerous factors specific to finance [17]. Three broad factors that pushed a move towards financial liberalization in the 1980s and 1990s were "poor results, high costs, and pressures from globalization" ([17], p. 208). The neoliberalism agenda according to [16] was an attempt to set back the clock to an earlier time of imperialist plundering of the planet, its peoples and its resources. Development partners were an important and integral part of the process of economic reforms. Their main contribution was provision of substantial financial and technical assistance and monitoring governments on implementation of economic reforms [18].

Most of the reforms in the natural resources sector in many countries in the south occurred in the 1990s. 
These reforms were supported by conservation multinationals, development multinationals, as well as many national departments for international cooperation [19]. The international policy instruments such as Convention on Biological Diversity and the Millennium Development Goals also supported these reforms. For instance, the Fifth IUCN World Parks Congress recommended that: “...protected area establishment and management should contribute to poverty reduction at the local level, and at the very minimum must not contribute to or exacerbate poverty” ([20], p. 210). The international agreements “pushed local conservation authorities to take the livelihood concerns of people residing in conservation landscapes seriously, leading to the continued search for on-the-ground mechanisms that can facilitate reconciliation between conservation and livelihood” ([9], p. 363).

\section{Market-Based Approaches to Biodiversity Conservation}

Since 1990s, market-based approaches to biodiversity conservation gained popularity in many countries [6]. The market-based conservation is fitted in neoliberalism that aims to reregulate nature through forms of commodification [21]. Neoliberalism "proposes that human well-being can best be advanced by liberating individual entrepreneurial freedoms and skills within an institutional framework characterized by strong private property rights, free markets and free trade” ([22], p. 2). The neoliberalisation priorities include deregulation, decentralisation, increased private sector involvement and withdrawal of the state in markets [23]. The state's role in the neoliberal context is to "create and preserve an institutional framework appropriate to such practices” ([22], p. 2).

Neoliberal conservation may take many forms, but it reframes conservation in terms of market mechanisms [21]. Neoliberal conservation can be defined as the "decentralisation of environmental governance, or a shift in responsibility for formal resource management from state to local institutions and new forms of commodification and commercialisation of nature that emerge in these contexts in order to fund conservation efforts" ([24], p. 10). Advocates of market-based conservation argue that such market will increase conservation fund, increase environment-friendly business practices, promote participatory conservation, protect native property rights, and promote environmental consciousness, thus enhancing more effective and efficient conservation [21]. Marketbased conservation has been linked with efforts to empower and economically improve the condition of most disadvantaged people, for example poor farmers, the landless, women and indigenous peoples [25]. Thus, the approach differ from traditional command and control approach to natural resources conservation as it allows actors to undertake actions that have the lowest cost but lead to more cost-effective results.

The main commodities for production and exchange in the market are mainly carbon, wildlife, landscape aesthetics, genetic resources and related knowledge, and ecosystem services. There have been major policy documents supporting this approach. These documents, among others, include: "The economics of ecosystems and biodiversity" [26] and "Towards a green economy” [27].

The economic rationale of market-based approaches is premised on the assumption that "if biodiversity and other environmental services are assigned market prices, market forces will drive biodiversity conservation ([28], p. 2). The requirements in these markets are mainly commodification, privatization, free trade locally, nationally and internationally. The approach is construed as a means to achieve development and environmental conservation in an environmentally sound way [9].

The main markets include payment for ecosystem services (PES) (also known as payment of environmental services) - focus on maintaining a flow of a specified ecosystem service in exchange for something of economic value. Examples under PES scheme include: carbon trade (Kyoto Protocol)_-The Protocol, adopted in Japan in 1997 and entered into force in 2005, is an international treaty that binds "State Parties to reduce greenhouse gases emissions" [29]. This Protocol was the first international attempt to fight climate change through the reduction of greenhouse gases emissions. The carbon trade emerged as an exchange of credits between nations. The trade was designed to reduce emissions of carbon dioxide. The trade allows countries that have higher carbon emissions to purchase the right to release more $\mathrm{CO}_{2}$ into the atmosphere from countries that have lower carbon emissions [30]. Natural forests and plantation are regarded as an important carbon sinks. Therefore, by allowing landowners to sell the carbon stored in these forests as emission reduction credits, will act as an incentive for forest conservation [6]. This argument has been embraced by the forestry sector in many countries as well as forest plantation companies, and has promoted the afforestation and reforestation projects [28]. Another form of PES is payments for watershed services-payments or direct compensations by the beneficiaries of a watershed service for the maintenance or provision of the service to its providers. 
Biodiversity offsets is another form of market where the conservation actions are intended to compensate for the residual, unavoidable harm to biodiversity caused by development projects, so as to ensure "no net loss" of biodiversity. However, before developers contemplate offsets, they should have first sought to avoid and minimise harm to biodiversity [31].

Forest Certification is another form of market that intends to ensure "sustainable forest management based on environmentally, socially beneficial and economically viable management of forests for present and future generations” ([32], p. 5). The certification concept emerged in the 1990s after many campaigns by environmental groups on the impact of timber logging on the environment. Examples of these campaigns include the "Boycott Tropical Timber" and "Save the Rainforest” of the 1970s and 1980s. The campaigns managed to raise awareness amongst consumers as well as putting pressure on the industry to use their purchasing power to influence practices in the trade. Based on this, timber producers, traders and environmentalists consent to establish the Forest Stewardship Council (FSC) in the early 1990s. Since then, a mechanism has been put in place to identify timber from genuine sources [33].

Trade in genetic resources and related knowledge is also considered as one of the markets. It is believed that if well managed, the market can be advantageous, since it can generate income for people, and at the same time provide incentives for the conservation of biodiversity. Another market is ecotourism. Ecotourism is defined as a "responsible travel to natural areas that conserves the environment and improves the wellbeing of local people" [34]. Tourism markets are believed to bring about win-win outcomes by adding value to protected areas through ecotourism activities and ecosystem services. This added value can pay for conservation activities and generate benefits for local communities, encouraging them to support conservation [6] [21].

Commercialisation of park management is another market where firms buy up public parks and reconstitute them on business principles. The typical example is the “African Parks Organisation”. The Organization manages ten parks in seven African countries_-Central Africa Republic, Chad, Democratic Republic of Congo, Malawi, Congo, Rwanda and Zambia. The total area under management covers six million hectares [35].

The market-based conservation is supported by international treaties and conventions (e.g. Convention of Biological Diversity, International Treaty on Plant Genetic Resources for Food and Agriculture), development partners (e.g. USAID), corporations, financial institutions (e.g. World Bank), organizations (e.g. World Intellectual Property Organization, the World Trade Organization), investors, governments, among many others [19] [20] [28].

\section{Persistent Narratives of Market-Based Conservation}

\subsection{Positive Impacts of Market-Based Conservation}

Market-based approaches are promoted as an opportunity for sustainable livelihoods. It enhances poverty reduction by providing livelihood opportunities, generating benefits for local communities and rational economic actors, and increasing democratization [6]. Furthermore, it enhances ecological sustainability, thus it is the most efficient and effective way of saving biodiversity [6]. Apart from that it relieves the states of the burden of conservation [6] [21]. Some literature supporting this claim includes [27] and [36].

Ecotourism in Africa is claimed to be “environmentally sustainable form of development” ([37], p. 131). For instance, in Tanzania there are ecotourism activities in different categories of protected areas such as in national parks and Wildlife Management Areas (WMAs). The WMAs are portions of village land set aside for wildlife conservation. Safari and hunting tourism are considered as the main source of income in these areas. Local people receive a share from tourism revenues and through this are motivated to support and participate in conservation. Thus, ecotourism is considered as a means to reconcile wildlife conservation and economic development. One of the WMAs practising ecotourism is the Enduimet WMA. This WMA has great commercial potential for tourism-has three tourists tented camps, and two hunting companies, several less frequent photographic tour companies. In 2010, members of Enduimet WMA received 45,941 USD [38]. Several studies have indicated ability of protected areas to reduce poverty (e.g. [11] [39]).

Positive impacts of carbon projects have been demonstrated through agricultural production, land tenure, conservation and livelihoods (e.g. [10] [40]). For example, findings from smallholder carbon projects in Africa where six projects managed by local and/or international NGOs were involved show that the projects enhanced crop yields and soil health-water holding capacity and making soils more resistant to drought, increased fodder and fuel wood [10]. In some cases, the development of the carbon projects led directly to solidification of tenure 
rights of communities. For instance in Humbo, Ethiopia, the carbon project development process, enabled people to get user certificates which granted them control of the resources in the project area [10]. Another example is the Makira REDD + Project in Madagascar where about 710,588 carbon credits were sold to Microsoft in 2014. Wildlife Conservation Society estimated that it could prevent the release of more than 32 million tonnes of $\mathrm{CO}_{2}$ over the next 30 years. The use of carbon credits was claimed to mitigate the impacts of climate change while protecting biodiversity and enhancing human livelihoods [40].

[41] reviewed eight case studies of payment for ecosystem services (PES). The findings show that the schemes provided small income to participating households also supported community services and infrastructure, particularly where revenues were made directly to community bodies. Likewise, [42] reviewed 44 case studies on PES. The studies show that the schemes can provide positive conservation and development outcomes with respect to livelihoods, household and community incomes, governance and land-use change. Also, [43] study in Cambodia on PES show that the programs had significant positive impacts on livelihoods for those that could afford to participate. In addition, the study by [39] indicates that PES can help to reduce poverty.

\subsection{Negative Impacts of Commercialization of Natural Resources}

It is argued that market-based conservation leads to primitive accumulation [44]/accumulation by dispossession [16] and green grabbing [45]. These terms have some similarities because all of them refer to appropriation of large tracts of land for economic ends. However, green grabbing refers to appropriation of land and resources in the name of green biofuels, carbon offsetting schemes, conservation activities and ecotourism initiatives [46]. Accumulation by dispossession is centralization of wealth and power in the hands of few by dispossessing the public their wealth or land [16], while primitive accumulation refers to taking land, enclosing it, and expelling a resident population to create landless proletariat and then leasing the land into the privatized mainstream of capital accumulation [45] [47]. Most of the land accumulated is last remnants of natural areas and local peoples' land. This process has negative impact on local people access to natural resources, food security, human rights, and the environment [48].

Market-based approaches alienate local people from their resources with hollow promises to involve them as significant partners and beneficiaries [38]. A study by [12] on carbon sink plantation in Uganda shows that local people were evicted from their ancestral land to make a space for plantations. Similarly, some WMAs in Tanzania have led to disappointments to local people as people were persuaded to demarcate their land for conservation, take management responsibility and benefit from the resources through tourism. However, this is not the case for instance in Enduimet WMA, as the central government retained the power of making strategic decisions over the WMA and only minimal benefits are realized. The revenue stream is centralised, there is lack of transparency of revenue flow and local communities are deprived control over revenue collection and distribution [49].

Besides, market-based mechanisms require clear ownership of land and resources so as to know who has the right to trade. Thus, it favours people with clear land title deed, and those with the investment capital, required expertise, social capital, and education [32]. The policies that support market-based approaches mainly attract and benefit large-scale landowners, who contribute towards market-based conservation [32]. Thus, marginal groups such as poor, forest-dependent people, indigenous peoples, and women are victims and disadvantaged in markets, as most of them do not have title deeds of land [50]-[52]. Women in particular, often own less (not own) properties, have less time to engage in development activities due to household chores, also lack information [38] [53]. In addition, the trade agreements do not support social safeguards in the biodiversity markets. For example, the liberalization of trade in ecosystem services under the General Agreement on Trade in Services and similar clauses in bilateral trade agreements indicate that giving priority and rights to local community discriminates against large companies [28].

Moreover, the schemes benefit outsiders than the affected community [50]. Also, the mechanisms aggravate already existing inequalities in the community due to its tendency to "redistribute upward rather than downward" [54] [55]. A study by [2] on who benefits from bio prospecting-driven commercialization of argan oil in Morocco show that the benefits that trickled down to local households were regressively distributed both regionally and between households. The bulk of gains accrued to non-locals and the process of commercialization induced changes in production, processing and distribution that excluded the poor. Another study conducted in Costa Rica on bio-prospecting shows that the scheme led to illegal appropriation of resources and limited economic 
benefits [32].

Studies show that the monetary powerful actors dominate the market and are able to negotiate and influence the rules of market (e.g. [32]). Thus, large and influential private companies, stand the better chance in the negotiation process from onset [56]. In addition, the significant financial returns accrued from the market, enhances dishonest companies to buy their way out of violations of environmental conservation laws. Besides, the criteria set by organizations such as the FSC for forests certification are often insufficient to meet the intended aims; and can sometimes be easily neglected or manipulated (e.g. [32] [33]).

Moreover, in these markets, there is no level playing field for producers and consumers. Thus, only economically powerful consumers are free to choose and only economically powerful producers are able to compete in the market [28]. This approach often is disadvantageous to marginal groups in the society, who lack economic power to enter the biodiversity market. Also, they are denied access to resources when land is privatized [50] [51] [57].

There are cases where these markets can lead to environmental destruction instead of environmental conservation, especially when economic incentives are meagre or unevenly distributed, and/or when the market based approach fail to deliver e.g. "no net loss" in biodiversity offsetting. [58] conclude that many of the expectations set by current offset policy for ecological restoration remain unsupported by evidence. Likewise, [59] examined natural forest management for high value timber, sale of non-timber forest products, and biodiversity prospecting. The findings show that all three schemes were generally unsuccessful in facilitating the conservation of the biological resources upon which the markets were based, except for a few cases operating under specific conditions.

Moreover, most schemes are unsustainable because most of them are external dependent mechanisms. For instance, almost all patrol activities in the Enduimet WMA are externally funded; the scheme will become unsustainable when external support ends unless the government intervenes by funding the activities after donor pull-out. However, experience from previous schemes such as Serengeti Regional Conservation Project [60] and Selous Conservation Programme [61] has indicated that there was minimal support from the Government when the donors ended their support. [62] also indicated that the market-based conservation projects in the Amazon did not meet development expectations partly because of the high costs borne by sponsoring organizations.

Furthermore, the benefit sharing mechanism incurs high transaction costs [49] [61] [63]. For instance studies from Costa Rica, Cambodia, Mexico, Tanzania, Mozambique and Ecuador on PES found that transaction costs can total up to $66 \%$ of the income generated through the schemes [63].

Furthermore, in most cases there are more costs than benefits to local populations [49]. For example in Enduimet WMA there are low revenue generation that does not come close to matching the opportunity costs borne by the communities. Wildlife damage to local people is too high and there is not compensation in most cases [38] [49]. Another study by [10] on six carbon projects in Africa show that for tree planting projects farmers were responsible for buying their own tree seedlings thus they incurred implementation costs. Carbon returns to farmers, in all six cases, were very low compared to the total costs of implementation. Other negative outcomes in the six carbon projects were conflicts among households or within them over land and carbon rights, tradeoffs between agricultural yield and carbon credit production, and conflicts within communities over the distribution of carbon payments, vague or weak land rights. Although, market-based mechanisms provide number of jobs to local people, the labour conditions are not favourable and many jobs are seasonal, with low wages [32].

Another shortcoming is rent seeking by different actors at different levels (see e.g. [64]). The corrupt governments through its corrupt officials and their allies can easily divert finances derived from market mechanisms [64]. Moreover, in countries where corruption is rampant, people with more power and influence are the ones securing the benefits from the markets.

Some studies show that not all values of biodiversity are included in the markets (e.g. [28]). It is difficult to quantify the cycles of nature (i.e. biodiversity balance, generation of water springs, pollination of insects, among many others). These values are mostly "invisible", and are not included in the markets [28].

\section{Conclusions}

The findings from various case studies demonstrate the strength and weaknesses of market-based approaches on conservation and development. On the one side, case studies have demonstrated that market based conservation can enhance biodiversity conservation, improve livelihoods, social services, and infrastructure, enhance good 
governance, enhance agricultural production and land tenure. On the other side, the case studies have shown that the schemes can favour owners of large tracts of land and powerful actors. Besides, the schemes benefit outsiders in most cases, can also lead to green grabbing and alienate people from their resources. Moreover, the schemes are affected by corruption; they lack transparency in revenue flow, and can lead to environmental destruction. Furthermore, flow of revenue incurs high transaction costs and the schemes are unsustainable because most of them are external dependent. In most cases, the victims are local communities particularly the poor, women, and indigenous people. Although, these schemes promise many powerful benefits for community, they remain unfulfilled. The benefits received in these schemes seldom outweigh associated costs.

As we have seen, the market-based approaches have much weakness but it is a vital component of efforts to combine conservation and development. The market-based conservation can be more effective and equitable if all biodiversity values are considered and equitably distributed to the proper owners. Also, if the market is properly regulated and there is an equitable participation of all biodiversity producers and consumers. All of these criteria have gender dimensions that should be emphasized and considered in the markets.

\section{References}

[1] Lybbert, T.J., Barrett, C.B. and Narjisse, H. (2004) Does Resource Commercialization Induce Local Conservation? A Cautionary Tale from Southwestern Morocco. Society and Natural Resources, 17, 413-430. http://dx.doi.org/10.1080/08941920490430205

[2] Lybbert, T.J., Barrett, C.B. and Narjisse, H. (2002) Market-Based Conservation and Local Benefits: The Case of Argan Oil in Morocco. Ecological Economics, 41, 125-144. http://dx.doi.org/10.1016/S0921-8009(02)00020-4

[3] Blackman, A. and Woodward, R.T. (2010) User Financing in a National Payments for Environmental Services Program: Costa Rican Hydropower. Ecological Economics, 69, 1626-1638. http://dx.doi.org/10.1016/j.ecolecon.2010.03.004

[4] Farley, J. and Costanza, R. (2010) Payments for Ecosystem Services: From Local to Global. Ecological Economics, 69, 2060-2068. http://dx.doi.org/10.1016/j.ecolecon.2010.06.010

[5] Beder, S. (2006) The Changing Face of Conservation: Commodification, Privatisation and the Free Market in Gaining Ground: In Pursuit of Ecological Sustainability. In: Lavigne, D.M., Ed., International Fund for Animal Welfare, Guelph, 83-97.

[6] Büscher, B.E. (2008) Conservation, Neoliberalism, and Social Science: A Critical Reflection on the SCB 2007. Annual Meeting in South Africa. Conservation Biology, 22, 229-231. http://dx.doi.org/10.1111/j.1523-1739.2008.00894.x

[7] McAfee, K. (1999) Selling Nature to Saveit? Biodiversity and the Rise of Green Developmentalism. Environment and Planning D: Society and Space, 17, 133-154. http://dx.doi.org/10.1068/d170133

[8] Pereira, S.N. (2010) Payment for Environmental Services in the Amazon Forest: How Can Conservation and Development be Reconciled? The Journal of Environment \& Development, 19, 171-190. http://dx.doi.org/10.1177/1070496510368047

[9] Roth, R. and Dressler, W. (2012) Market-Oriented Conservation Governance: The Particularities of Place. Intro to Special Issue. Geoforum, 43, 363-366. http://dx.doi.org/10.1016/j.geoforum.2012.01.006

[10] Shames, S., Wollenberg, E., Buck, L.E., Kristjanson, P., Masiga, M. and Biryahaho, B. (2012) Institutional Innovations in African Smallholder Carbon Projects. CCAFS Report No. 8. Copenhagen, Denmark: CGIAR Research Program on Climate Change, Agriculture and Food Security (CCAFS). www.ccafs.cgiar.org

[11] Andam, K.S., Ferraro, P.J., Sims, K., Healy, A. and Holland, M. (2010) Protected Areas Reduced Poverty in Costa Rica and Thailand. Proceedings of the National Academy of Sciences, 107, 9996-10001. http://dx.doi.org/10.1073/pnas.0914177107

[12] Carrere, R. (2009) Carbon Sink Plantation in Uganda: Evicting People for Making Space for Trees. In: Böhm, S. and Dahbi, S., Eds., Upsetting the Offset: The Political Economy of Carbon Markets, Mayfly Books, London, 98-101.

[13] Adams, W.M. (2004) Against Extinction: The Story of Conservation. Earthscan, London, 16, 311.

[14] TRA (Theodore Roosevelt Association) The Hunter, n.d. http://www.theodoreroosevelt.org/site/c.elKSIdOWIiJ8H/b.8344379/k.2B69/The Hunter.htm

[15] Bluffstone, R. and Robinson, E.J.Z. (2014) Forest Tenure Reform in Asia and Africa: Local Control for Improved Livelihoods, Forest Management, and Carbon Sequestration. Environment for Development, RFF Press, London, 284.

[16] Harvey, D. (2003) The New Imperialism. Oxford University Press, Oxford.

[17] WB (World Bank) (2005) Financial Liberalization: What Went Right, What Went Wrong? Economic Growth in the 1990s: Learning from a Decade of Reform, World Bank, Washington DC. 
[18] Muganda, A. (2004) Tanzania’s Economic Reforms-And Lessons Learned. Scaling Up Poverty Reduction: A Global Learning Process Conference, Shanghai, 25-27 May 2004. http://www.tanzaniagateway.org/docs/tanzania_country_study_full_case.pdf

[19] Inamdar, A., de Jode, H., Lindsay, K. and Cobb, S. (1996) Capitalizing on Nature: Protected Area Management. Science, 283, 1856-1857. http://dx.doi.org/10.1126/science.283.5409.1856

[20] IUCN (2003) Recommendations. The 5th World Parks Congress, Durban, 8-17 September 2003. https:/www.iucn.org/about/work/programmes/gpap_home/gpap_events/gpap_wpc/copy_of_wcpa_wpc_31082012_1316/

[21] Igoe, J. and Brockington, D. (2007) Neoliberal Conservation: A Brief Introduction. Conservation and Society, 5, 432449.

[22] Harvey, D. (2005) A Brief History of Neoliberalism. Oxford University Press, New York.

[23] Levine, A. (2007) Staying Afloat: State Agencies, Local Communities, and International Involvement in Marine Protected Area Management in Zanzibar, Tanzania. Conservation and Society, 5, 562-585.

[24] Brondo, K.V. (2013) Land Grab: Green Neoliberalism, Gender, and Garifuna Resistance in Honduras. University of Arizona Press, Tucson, 240 p.

[25] Neumann, R.P. (2000) Primitive Ideas: Protected Area Buffer Zones and the Politics of Land in Africa? Nordiska Afrikainstitutet, Uppsala, 220-242.

[26] TEEB (2010) The Economics of Ecosystems and Biodiversity: Mainstreaming the Economics of Nature. A Synthesis of the Approach, Conclusions and Recommendations of TEEB.

[27] UNEP (2011) Towards a Green Economy: Pathways to Sustainable Development and Poverty Eradication-A Synthesis for Policy Makers. www.unep.org/greeneconomy

[28] GFC (Global Forest Coalition) (2008) Life as Commerce: The Impact of Market-Based Conservation Mechanisms on Women. The Global Forest Coalition. http://vh-gfc.dpi.nl/img/userpics/File/publications/LIFE-AS-COMMERCE2008.pdf

[29] IPCC (2015) Climate Change 2014: Synthesis Report. Summary for Policy Makers. http://www.ipcc.ch/pdf/assessment-report/ar5/syr/AR5_SYR_FINAL_SPM.pdf

[30] UNFCC (United Nations Framework Convention on Climate Change) (2014) International Emissions Trading: Greenhouse Gas Emissions-A New Commodity. http://unfccc.int/kyoto_protocol/mechanisms/emissions_trading/items/2731.php

[31] Kate, K., Bishop, J. and Bayon, R. (2004) Biodiversity Offsets: Views, Experience, and the Business Case. IUCN, Gland, Switzerland and Cambridge, UK and Insight Investment, London, UK.

[32] GFC (Global Forest Coalition) (2008) Life as Commerce: The Impact of Market-Based Conservation on Indigenous Peoples, Local Communities and Women. GFC, Asunción.

[33] Magin, G. (2008) Forest Certification-What Does It Mean for the World's Forests? Botanic Gardens Conservation International. https://www.bgci.org/resources/article/0579/

[34] TIES (The International Ecotourism Society) (2011) What Is Ecotourism? http://www.ecotourism.org/what-is-ecotourism

[35] APO (African Parks Organization) (n.d.) Our Story. https://www.african-parks.org/african-parks/our-story

[36] Simpson, R.D. (2004) Conserving Biodiversity through Markets: A Better Approach. PERC (Property and Environment Research Centre) Policy Series PS-32, USA.

[37] Duffy, R. (2006) Global Environmental Governance and the Politics of Ecotourism in Madagascar. Journal of Ecotourism, 5, 128-144. http://dx.doi.org/10.1080/14724040608668451

[38] Mariki, S.B. (2016) Social Impacts of Conservation on Gender in West Kilimanjaro Tanzania. Open Journal of Social Sciences, 4, 220-235. http://dx.doi.org/10.4236/jss.2016.43028

[39] Pagiola, S., Arcenas, A. and Platais, G. (2005) Can Payments for Environmental Services Help Reduce Poverty? An Exploration of the Issues and the Evidence to Date from Latin America. World Development, 33, 237-253. http://dx.doi.org/10.1016/j.worlddev.2004.07.011

[40] Butler, R. (2014) Microsoft Buys Madagascar Carbon Credits. http://news.mongabay.com/2014/02/microsoft-buys-madagascar-carbon-credits/

[41] Mahanty, S., Suich, H. and Tacconi, L. (2013) Access and Benefits in Payments for Environmental Services and Implications for REDD+: Lessons from Seven PES Schemes. Land Use Policy, 31, 38-47. http://dx.doi.org/10.1016/j.landusepol.2011.10.009

[42] Hejnowicz, A.P., Raffaelli, D.G., Rudd, M.A. and White, P.C.L. (2014) Evaluating the Outcomes of Payments for Ecosystem Service Programmes Using a Capital Asset Framework. Ecosystem Services, 9, 83-97. 
http://dx.doi.org/10.1016/j.ecoser.2014.05.001

[43] Clements, T. and Milner-Gulland, E.J. (2014) Impact of Payments for Environmental Services and Protected Areas on Local Livelihoods and Forest Conservation in Northern Cambodia. Conservation Biology, 29, 78-87. http://dx.doi.org/10.1111/cobi.12423

[44] Marx, K. (1976) Capital: A Critique of Political Economy. Vol. 1, Penguin, London.

[45] Kelly, A. (2011) Conservation Practice as Primitive Accumulation. Journal of Peasant Studies, 38, 638-701. http://dx.doi.org/10.1080/03066150.2011.607695

[46] Fairhead, J., Leach, M. and Scoones, I. (2012) Green Grabbing: A New Appropriation of Nature? Journal of Peasant Studies, 39, 237-261. http://dx.doi.org/10.1080/03066150.2012.671770

[47] Büscher, B. (2009) Letters of Gold: Enabling Primitive Accumulation through Neoliberal Conservation. Human Geography, 2, 91-94.

[48] Global Witness, Oakland Institute, International Land Coalition (2012) Dealing with Disclosure: Improving Transparency in Decision-Making over Large-Scale Land Acquisitions and Investments. http://www.landcoalition.org/sites/default/files/documents/resources/Dealing_with_disclosure.pdf

[49] Mariki, S.B., Svarstad, H. and Benjaminsen, T.A. (In Press) Ecotourism in Enduimet: An Examination of Local Benefits and Transparency in a Wildlife Management Area in Tanzania. In: Rutten, M. and Wijngaarden, V., Eds., Ecotourism in Africa: Experiences from Kenyan and Tanzanian Maasailand, African Dynamic Series, Brill, Leiden.

[50] Brockington, D., Duffy, R. and Igoe, J. (2008) Nature Unbound: Conservation, Capitalism, and the Future of Protected Areas. Earthscan, London.

[51] Adams, W. and Hutton, J. (2007) People, Parks and Poverty: Political Ecology and Biodiversity Conservation. Conservation and Society, 5, 147-183.

[52] Balmford, A. and Whitten, T. (2003) Who Should Pay for Tropical Conservation, and How Could the Costs Be Met? Oryx, 37, 238-250. http://dx.doi.org/10.1017/S0030605303000413

[53] Ogra, M. (2008) Human-Wildlife Conflict and Gender in Protected Area Borderlands: A Case Study of Costs, Perceptions, and Vulnerabilities from Uttarakhand (Uttaranchal), India. Geoforum, 39, 1408-1422. http://dx.doi.org/10.1016/j.geoforum.2007.12.004

[54] Dressler, W. (2009) Reinforcing Local Inequity and Resistance through Community-Based Conservation on Palawan Island, the Philippines. In: Turner, S. and Caouette, D., Eds., Agrarian Angst and Rural Resistance in Contemporary Southeast Asia, Routledge Press, Abingdon.

[55] McAfee, K. (2012) Nature in the Market-World: Ecosystem Services and Inequality. Development, 55, 25-33. http://dx.doi.org/10.1057/dev.2011.105

[56] Nelson, F. (2012) Blessing or Curse? The Political Economy of Tourism Development in Tanzania. Journal of Sustainable Tourism, 20, 359-375. http://dx.doi.org/10.1080/09669582.2011.630079

[57] Colchester, M. (2002) Wilderness Parks or Community Conservation? World Rainforest Movement's Bulletin, No. 62, Uruguay.

[58] Maron, M., Hobbs, R.J., Moilanen, A., Matthews, J.W., Christie, K., Gardner, T.A., Keith, D.A., Lindenmayer, D.B. and McAlpine, C.A. (2012) Faustian Bargains? Restoration Realities in the Context of Biodiversity Offset Policies. Biological Conservation, 155, 141-148. http://dx.doi.org/10.1016/j.biocon.2012.06.003

[59] Crook, C. and Clapp, R. (1998) Is Market-Oriented Forest Conservation a Contradiction in Terms? Environmental Conservation, 25, 131-145. http://dx.doi.org/10.1017/S0376892998000186

[60] Kideghesho, J.R., Nyahongo, J.W., Hassan, S.N., Tarimo, T.C. and Mbije, N.E. (2006) Factors and Ecological Impacts of Wildlife Habitat Destruction in the Serengeti Ecosystem in Northern Tanzania. AJEAM-RAGEE, 11, 917-932.

[61] Songorwa, A. (1999) Community Based Wildlife Management in Tanzania: Are Communities Interested? World Development, 27, 2061-2079. http://dx.doi.org/10.1016/S0305-750X(99)00103-5

[62] Pokorny, B., Johnson. J., Medina, G. and Hoch, L. (2012) Market-Based Conservation of the Amazonian Forests: Revisiting Win-Win Expectations. Geoforum, 43, 387-401. http://dx.doi.org/10.1016/j.geoforum.2010.08.002

[63] Alston, L.J., Andersson, K. and Smith, S.M. (2013) Payment for Environmental Services: Hypotheses and Evidence. Annual Review of Resource Economics, 5, 139-159. http://dx.doi.org/10.1146/annurev-resource-091912-151830

[64] Benjaminsen, T.A., Goldman, M., Minwary, M. and Maganga, F. (2013) Wildlife Management in Tanzania: State Control, Rent Seeking and Community Resistance. Development and Change, 44, 1087-1109. http://dx.doi.org/10.1111/dech.12055 


\section{Submit or recommend next manuscript to SCIRP and we will provide best service for you:}

Accepting pre-submission inquiries through Email, Facebook, Linkedin, Twitter, etc A wide selection of journals (inclusive of 9 subjects, more than 200 journals)

Providing a 24-hour high-quality service

User-friendly online submission system

Fair and swift peer-review system

Efficient typesetting and proofreading procedure

Display of the result of downloads and visits, as well as the number of cited articles

Maximum dissemination of your research work

Submit your manuscript at: http://papersubmission.scirp.org/ 